\title{
Integrated Regulation of Signal Coding and Plasticity by NMDA Receptors at a Central Synapse
}

\author{
Egidio D'Angelo ${ }^{\dagger}$ and Paola Rossi \\ Istituto di Fisiologia Generale, and Istituto Nazionale Fisica della Materia (INFM), \\ Pavia Unit, Via Forlanini 6, I-27100, Pavia, Italy
}

\section{SUMMARY}

The role of NMDA and non-NMDA glutamate receptors in long-term potentiation has been intensely investigated, yet recent evidence on the dynamics of synaptic depolarization suggests that the original view should be extended. NMDA receptor-mediated currents, apart from their $\mathrm{Ca}^{2+}$ permeability, show a marked voltage dependence, consisting of current increase and slowdown during membrane depolarization. During highfrequency synaptic transmission, NMDA current increase and slowdown are primed by non-NMDA receptor-dependent depolarization and proceed regeneratively. Thus, NMDA receptors make a decisive contribution to membrane depolarization and spike-firing. From the data obtained at the mossy fibergranule cell synapse of the cerebellum, we propose that the electrogenic role of NMDA receptors is functional to LTP induction. Moreover, during LTP, both NMDA and nonNMDA receptor currents are potentiated, thus establishing a feed-forward mechanism that ultimately enhances spike firing. Thus, NMDA receptors exert an integrated control on signal coding and plasticity. This mechanism may have important implications for information processing at the cerebellar mossy fibergranule cell relay.

\footnotetext{
${ }^{\dagger}$ Corresponding author

Tel: +0039-382-507-606

Fax: +0039-382-507-527

e-mail: dangelo@ipv36.unipv.it
}

\section{KEYWORDS}

synaptic transmission, LTP, cerebellum granule cells, NMDA receptors

\section{INTRODUCTION}

Synaptic transmission at glutamatergic synapses of the vertebrate central nervous system is brought about by the activation of N-methyl-Daspartate (NMDA) and non-NMDA receptors. In the past decade, several investigations have addressed the biophysical and molecular aspects of glutamatergic transmission (for review, see McBain, 1994; Edmonds et al., 1995; Kaczmarek et al., 1997). In particular, the relevance of glutamate-channel properties to synaptic plasticity [long-term potentiation (LTP) and long-term depression (LTD)] has been revealed (Bliss \& Collingridge, 1993; Bear \& Malenka, 1994). Yet, recent evidence on the dynamics of synaptic depolarization suggests that an extension of the original view is needed.

\section{FUNCTIONAL PROPERTIES OF NMDA RECEPTORS}

NMDA receptors show complex functional properties. NMDA receptors are associated with an ionic channel that is blocked by $\mathrm{Mg}^{2+}$ at negative membrane potentials (Nowak et al., 1984; Mayer et al., 1984). Once unblocked, the NMDA channel is highly permeable to $\mathrm{Ca}^{2+}$ (Mayer \& Westbrook, 1987; Iino et al., 1990). The permeability allows a synaptic regulation of $\mathrm{Ca}^{2+}$ influx, which is of fundamental importance 
A
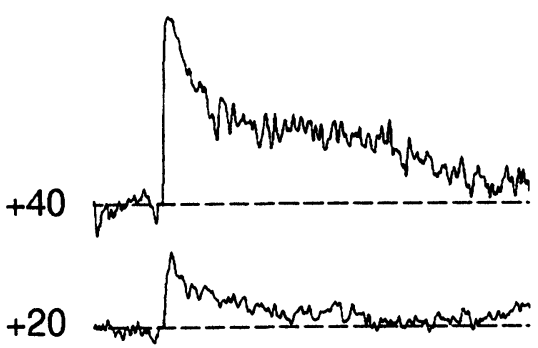

$10 \mathrm{pA} \bigsqcup_{100 \mathrm{~ms}}$

0
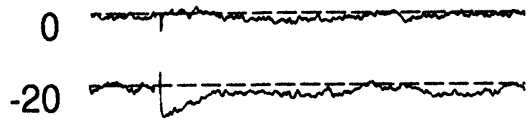

$-40$

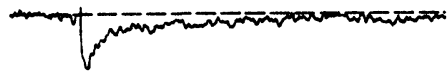

$-60$

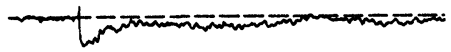

B
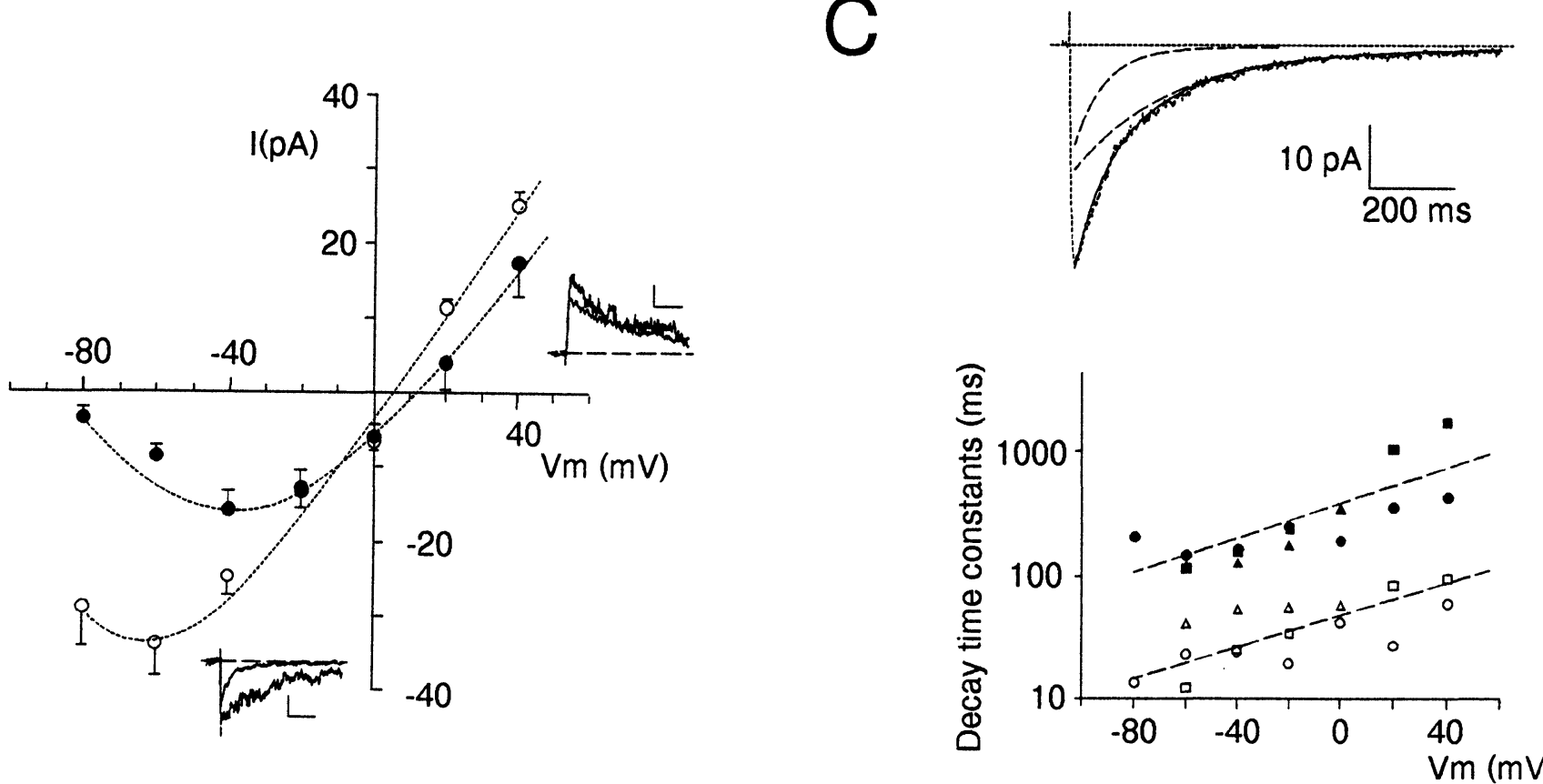

Fig. 1: Voltage-dependent kinetics of cerebellar granule cell NMDA receptor-mediated synaptic currents (the non-NMDA currents have been blocked by $10 \mu \mathrm{M}$ CNQX). (A) The NMDA current shows slower kinetics as the holding potential is increased. (B) Negative slope conductance in peak NMDA current is reduced by $\mathrm{Mg}^{2+}$ removal from the extracellular solution $\left(-1.2 \mathrm{mM} \mathrm{Mg}^{2+} ; \mathrm{O}\right.$ no added $\left.\mathrm{Mg}^{2+}\right)$. Insets compare the NMDA currents measured at $-40 \mathrm{mV}$ and $+40 \mathrm{mV}$, before and after $\mathrm{Mg}^{2+}$ removal (scale bars $20 \mathrm{pA}-100 \mathrm{~ms}$ ). Single channel transitions observed after $\mathrm{Mg}^{2+}$ removal correspond to the opening of individual NMDA channels (see Silver et al., 1992; D'Angelo et al., 1993). (C) The NMDA current can be fitted by a double exponential function (individual exponential curves are shown as broken lines). Voltage-dependence of the two decay time constants is reported in a semi-logarithmic plot for three granule cells. Data partly from D'Angelo et al. $(1993,1994)$. 
for the induction of synaptic plasticity (Bliss \& Collingridge, 1993; Bear \& Malenka, 1994). A second property that has been less considered so far is that NMDA receptor-mediated synaptic currents slow down during membrane depolarization (Keller et al., 1991).

On the basis of experiments carried out at the mossy fiber-granule cell synapse of the cerebellum, we propose that NMDA current voltagedependent kinetics are also functional to LTP induction.

\section{WHOLE-CELL RECORDINGS FROM GRANULE CELLS IN RAT CEREBELLAR SLICES}

The results reported in this paper extend our previous work on rat cerebellar granule cells (D'Angelo et al., 1993-1995; 1997a; Rossi et al., 1996; see also Silver et al., 1992). The present experiments were performed using the whole-cell configuration of the patch-clamp in cerebellar slices (Edwards et al., 1989). Synaptic currents were elicited by electrical stimulation of the mossy fiber bundle. Owing to the simplified organization of their dendritic structure and mossy fiber input, cerebellar granule cells are electrotonically compact, and a direct relationship between synaptic current properties and effects on neuronal excitability can be established.

Voltage-dependent $\mathrm{Mg}^{2+}$ block and decay kinetics, which were revealed at the mossy fibergranule cell synapse of the cerebellum (D'Angelo et al., 1993, 1994; Fig. 1), are related to the generation of sustained depolarization during repetitive transmission (D'Angelo et al., 1995; Fig. 2). Recently, we demonstrated that NMDA synaptic currents are also involved in LTP generation (Rossi et al., 1996; D'Angelo et al., 1997b; D'Angelo et al., unpublished; Fig. 3).

\section{NMDA RECEPTOR-DEPENDENT REGULATION OF SYNAPTIC TRANSMISSION}

During low-frequency transmission, nonNMDA receptors are almost entirely responsible for synaptic depolarization (Collingridge et al., 1988a,b; Collingridge, 1992). Nonetheless, a contribution of NMDA receptors was revealed (Fig. 2A) in the large-size excitatory postsynaptic potentials (EPSP) of cerebellar granule cells, in which the $\mathrm{Mg}^{2+}$ block is removed, and the NMDA current slows down. In these conditions, the NMDA current increases the EPSP amplitude and protracts EPSP decay (D'Angelo et al., 1995). An NMDA receptor contribution to low-frequency EPSPs is particularly evident in immature synapses, which show a high NMDA/non-NMDA current ratio (D'Angelo et al., 1993, 1997a).

A critical contribution of the NMDA current occurs in cerebellar granule cells during highfrequency synaptic activity (Fig. 2B), when the NMDA current sustains membrane depolarization and spike firing (D'Angelo et al., 1995). Apparently, the role of non-NMDA currents is to prime the regenerative cycle protracting NMDA current duration. Non-NMDA currents, however, undergo a strong depression during the burst, so that their direct contribution to depolarization is small. Non-NMDA current depression is probably due to channel desensitization (Trussel et al., 1993; Silver et al., 1996), whereas NMDA current desensitization is prevented by glycine, a coagonist of glutamate at the NMDA receptor (Mayer et al., 1989).

It turns out that, during repetitive highfrequency synaptic transmission, the NMDA current greatly enhances synaptic depolarization and spike firing (Fig. 2C). This effect is important because repetitive high-frequency burst firing is a common mode of information coding in neuronal networks, simultaneously providing an adequate stimulus for the induction of LTP.

\section{NMDA RECEPTOR-DEPENDENT REGULATION OF SYNAPTIC PLASTICITY}

The best known form of synaptic plasticity is LTP, a candidate for the deposition of memory in neuronal circuits (Bliss \& Collingridge, 1993). LTP consists of a brief induction phase, driven by bursts of high-frequency synaptic impulses or by various pairing procedures, followed by a longlasting expression phase, during which synaptic 

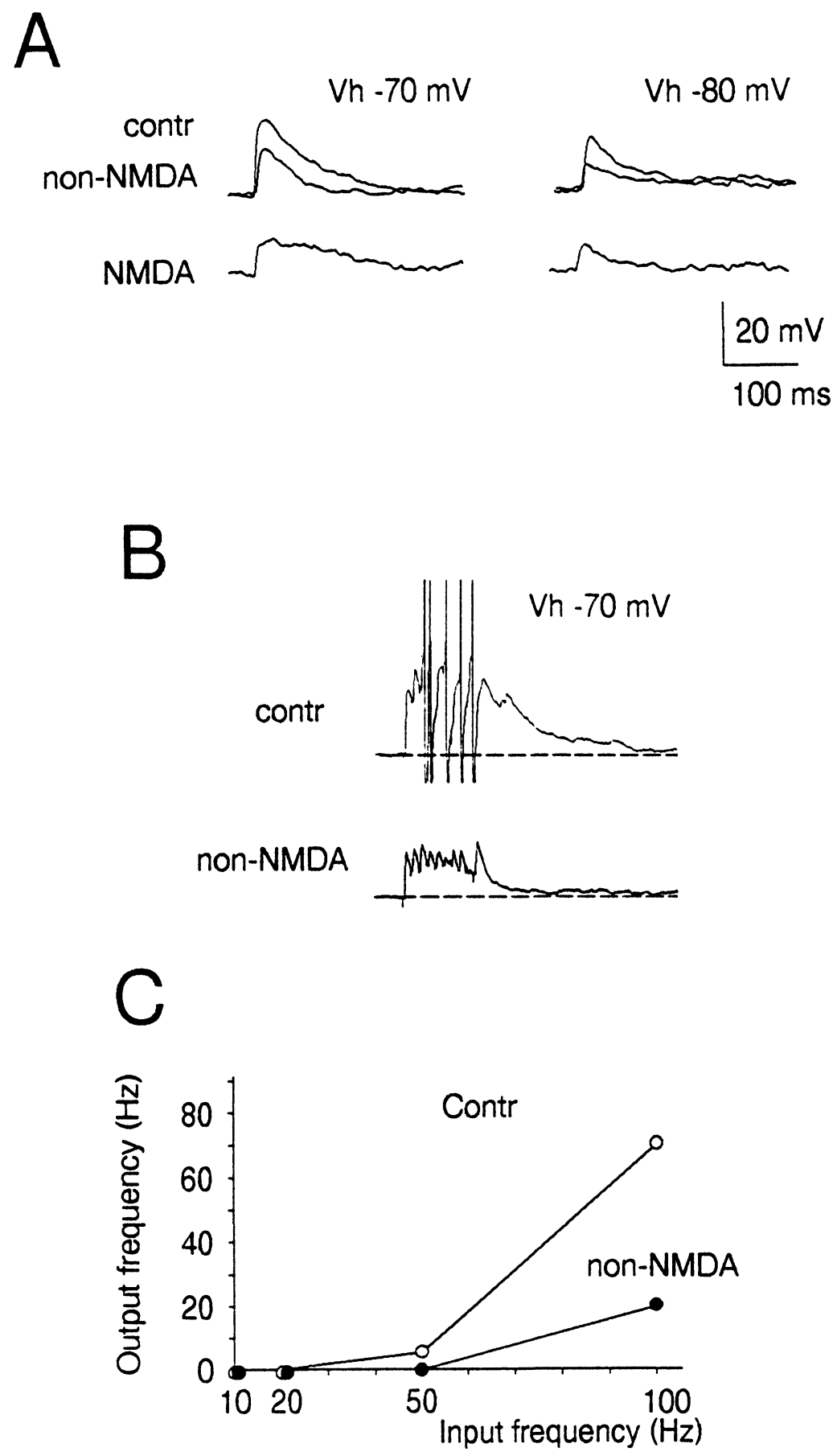

Fig. 2: NMDA receptor-mediated responses during mossy fiber activation of cerebellar granule cells. (A) The contribution of the NMDA current to EPSP elicited by low-frequency stimulation was uncovered by subtracting the non-NMDA EPSP (100 $\mu \mathrm{M}$ APV $+50 \mu \mathrm{M} 7$-chlorokinurenic acid) from control EPSP. The NMDA current slows down the EPSP decay, and enhances EPSP peak. Two EPSPs are compared, visiting the $-70 /-48 \mathrm{mV}$ and the $-80 /-63 \mathrm{mV}$ membrane potential ranges, respectively. Note the greater NMDA current contribution when the EPSP traverses the higher membrane potential range. Neither EPSP reached threshold for spike activation $(-41 \mathrm{mV})$. (B) Block of repetitive discharge during repetitive $50 \mathrm{~Hz}$ stimulation by NMDA receptor antagonists $(100 \mu \mathrm{M}$ APV $+50 \mu \mathrm{M} 7-$ chlorokinurenic acid). Note depression of residual non-NMDA responses during the stimulus train. Same scale as in A. (C) Blocking NMDA receptors caused a strong depression of the granule cell input-output function. In this plot, the input was the frequency of mossy fiber stimulation, the output was the frequency of granule cell spikes during the synaptic burst. Data obtained from D'Angelo et al., 1995. 


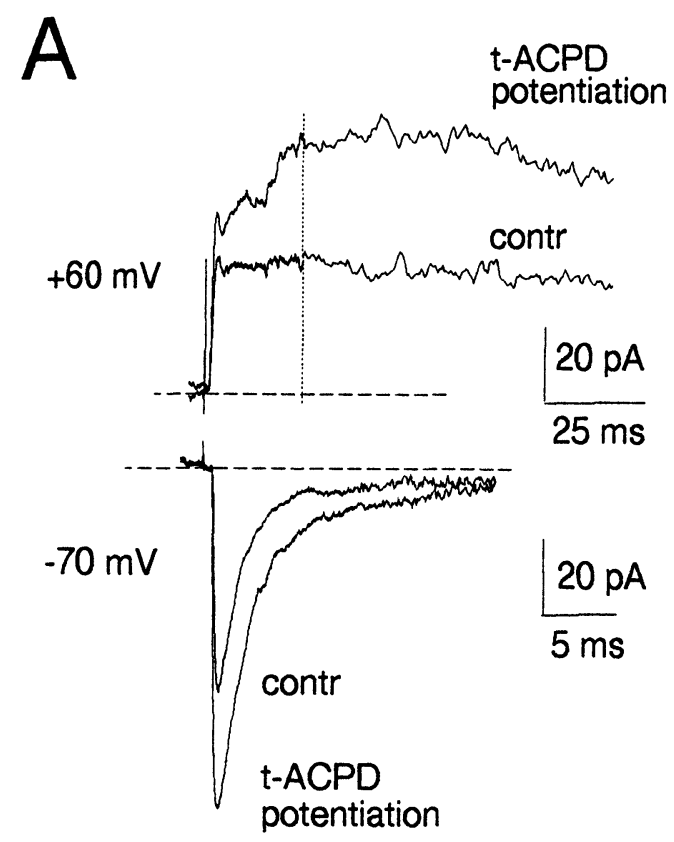

B
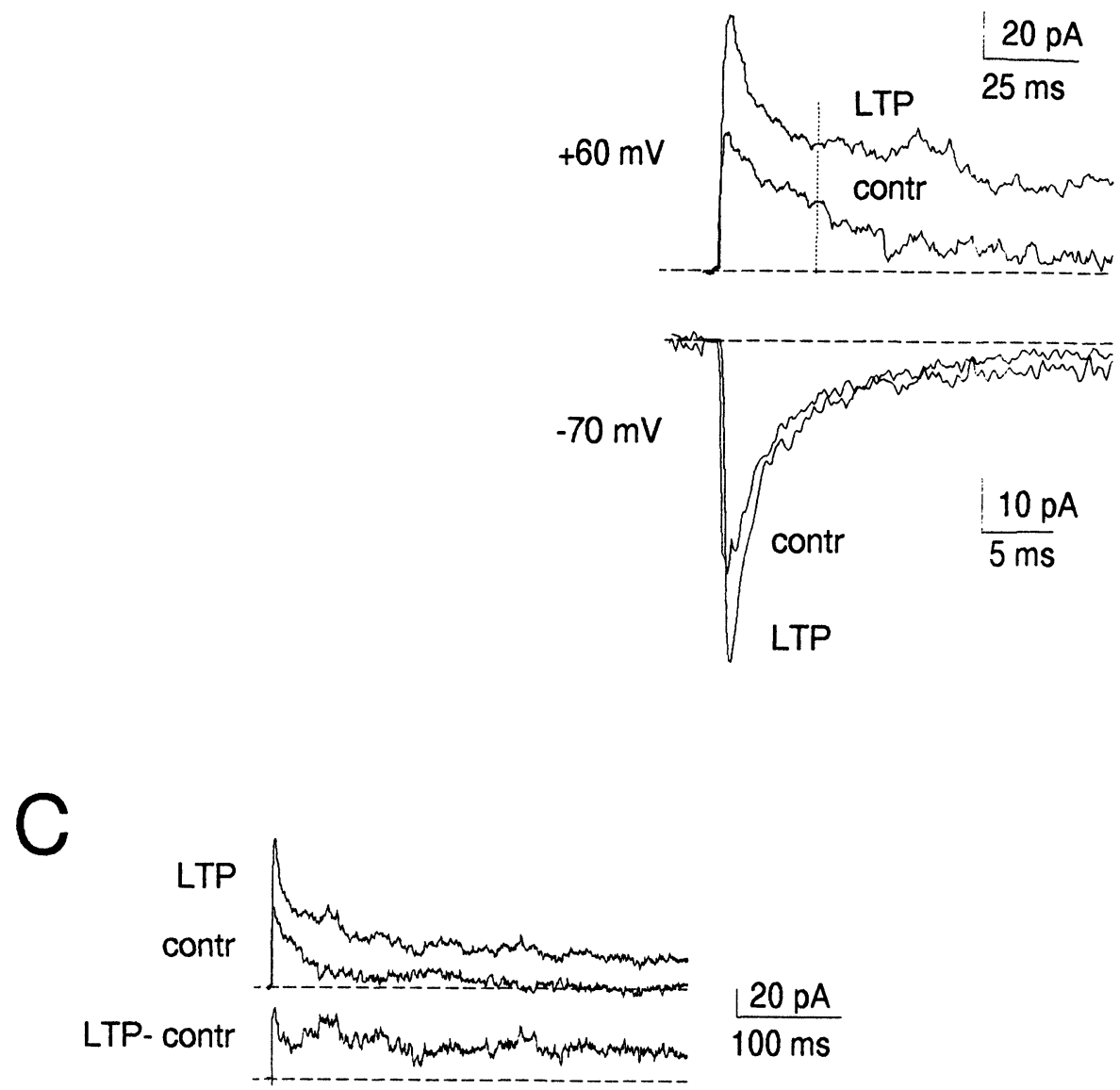

Fig. 3: Potentiation of mossy fiber-granule cell synaptic currents. After induction, both the non-NMDA current (peak amplitude at $-70 \mathrm{mV}$ ) and the NMDA current (dotted line at $+60 \mathrm{mV}$ ) were increased. Potentiation was induce by (A) low-frequency NMDA receptor synaptic activation $(0.1 \mathrm{~Hz})$ paired with a 60 -sec application of the metabotropic glutamate receptor agonist $20 \mu \mathrm{M} \mathrm{t}$-ACPD, or by (B) high-frequency NMDA receptor synaptic activation ( 8 bursts of 10 impulses at $100 \mathrm{~Hz}$ every $250 \mathrm{~ms}$ ) paired with membrane depolarization to $-40 \mathrm{mV}$. (C) Subtraction of control from potentiated tracings at $+60 \mathrm{mV}$ showed that the NMDA current increased in a slow component (same cell as in B). Data in A obtained from Rossi et al., 1996. 
transmission is potentiated (Fig. 3 A,B). As at other glutamatergic synapses, LTP induction at the mossy fiber-granule cell synapse depends on NMDA receptors (Rossi et al., 1996; D'Angelo et al., 1997b; D'Angelo et al., unpublished; Fig. 3C). NMDA receptors, by causing $\mathrm{Ca}^{2+}$ influx through the associated channel, activate the intracellular $\mathrm{Ca}^{2+}$-dependent mechanisms leading to LTP. To unblock NMDA channels from $\mathrm{Mg}^{2+}$, the postsynaptic neuron must be depolarized.

As at other glutamatergic synapses (see also O'Connor et al., 1995; Clark \& Collingridge, 1995; Kullman et al., 1996), during LTP expression at the mossy fiber-granule cell synapse, both the NMDA and non-NMDA are potentiated. Moreover, the NMDAcurrent slows down considerably (Fig. 3C), apparently in relation with a selective increase in the slow component of NMDA-EPSC decay (Rossi et al., 1996).

\section{INTEGRATED NMDA RECEPTOR-DEPENDENT CONTROL OF SYNAPTIC TRANSMISSION AND PLASTICITY}

It emerges that NMDA receptors, by enhancing synaptic depolarization during high frequency transmission, operate an integrated control of signal coding and plasticity. The nodal point is that NMDA receptor activation is critical for membrane electrogenesis, simultaneously controlling the output frequency of the neuron and (through $\mathrm{Ca}^{2+}$ influx) the induction of LTP (Fig. 4).
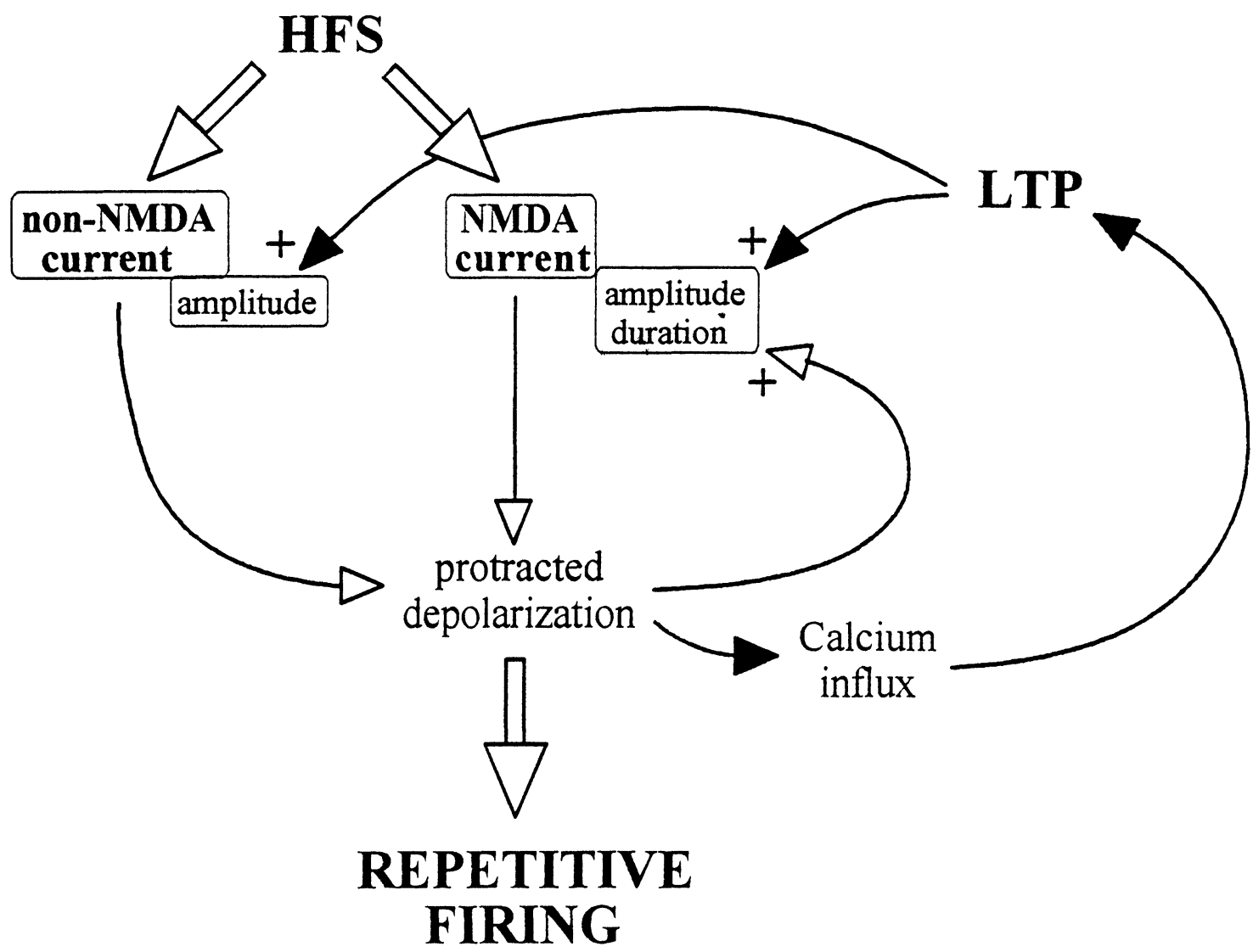

Fig. 4: Integrated regulation of signal coding and plasticity by NMDA receptors. In this model, NMDA-receptor activation is critical for both membrane electrogenesis and $\mathrm{Ca}^{2+}$ influx. At the core of this process remains a voltage-dependent increase in size and duration of the NMDA current during membrane depolarization, with non-NMDA receptors priming the regenerative process. The NMDA receptors, by increasing their own responsiveness, configure the system in feed-forward mode. Note that the final effect will be an enhancement of repetitive firing, and therefore of the input-output function of the neuron. 
At the core of this process is the voltagedependent increase in the size and duration of the NMDA current during membrane depolarization. Non-NMDA receptors would have the important role of priming the regenerative NMDA current increase. Once LTP is established, the increase in non-NMDA and NMDA currents, and the slowdown in NMDA current, enhance membrane depolarization and spike firing. In the model proposed in Fig. 4, NMDA receptors increase their own responsiveness after high-frequency transmission. Thus, the system is configured in feed-forward mode, rendering the potentiated synapses particularly susceptible to develop further LTP (Bortolotto et al., 1994). In practice, once the induction threshold is crossed, LTP should tend toward saturation. Although a feedforward mechanism is attractive because it ensures a high reliability for LTP induction, such a mechanism intrinsically requires a negative control. Beside numerous LTP modulatory mechanisms, GABA-receptor-mediated synaptic inhibition is an interesting candidate as, by preventing membrane depolarization, it would break down the electrogenic mechanism that is based on regenerative NMDA current activation. It should be noted that most synaptic inhibition may be effective at low frequency, but be turned off by $\mathrm{GABA}_{\mathrm{B}}$ autoreceptors at high-frequency. Therefore, synaptic inhibition may accentuate the all-or-none behavior of the system (Bliss \& Collingridge, 1993; Davies \& Collingridge, 1997).

\section{A WIDESPREAD PROPERTY OF GLUTAMATERGIC SYNAPSES?}

The model proposed in Fig. 4 is largely based on observations on mature cerebellar granule cells, in which NMDA receptors express the NR2-A and NR2-C subunits (Ebralidize et al., 1996; Takahashi et al., in press). Regional and ontogenetic differences in NMDA-receptor subunits affect NMDA receptor properties (see Monyer et al., 1994). We present evidence below, however, suggesting that an integrated NMDA receptor-dependent control of synaptic transmission and plasticity may be effective in different brain areas.

In hippocampal synapses, the NMDAreceptor-mediated synaptic current and its role in synaptic plasticity have been very extensively characterized. At the perforant path-granule cell synapse, NMDA receptors contribute to synaptic transmission (Lambert \& Jones, 1990), and the NMDA current shows marked voltage-dependent kinetics (Keller et al., 1991). Moreover, at this synapse, NMDA receptors are both required for LTP induction and potentiated during LTP expression (O'Connor et al., 1995). The perforant path-granule cell synapse is, therefore, a good candidate for an integrated NMDA-receptormediated control of synaptic transmission and plasticity. At the Shaffer collateral-CA1 synapse, NMDA receptors are likewise involved in both LTP induction and expression (Clark \& Collingridge, 1995). Nevertheless, NMDA current voltage dependence is weak (Hestrin et al., 1990), and synaptic transmission is largely sustained by non-NMDA receptors (Collingridge et al., 1987a,b). The applicability of our model to the Shaffer collateral-CA1 synapse is less clear than it is to the perforant path-granule cell synapse.

Functional evidence for a dual role of NMDA receptors in signal coding and synaptic plasticity is found in the visual system. In the lateral geniculate nucleus, NMDA receptors sustain high-frequency transmission of visual information (Heggelund \& Hartveit, 1990; Turner et al., 1994). In the visual cortex, NMDA receptors are necessary to both mediate the visual response (Miller et al., 1989) and generate LTP (Artola \& Singer, 1992). Interestingly, ocular dominance plasticity requires NMDA-receptor activation during normal synaptic transmission (Kasamatsu et al., 1998). Thus, the functional role of NMDA receptors in the visual system is compatible with the model proposed here.

\section{CONCLUSIONS}

By including the dynamics of postsynaptic membrane depolarization during repetitive highfrequency synaptic transmission into the previous knowledge on LTP, we have extended the 
functional implications of NMDA receptors. NMDA receptors exert an integrated control on signal coding and plasticity, which is especially relevant during repetitive high-frequency synaptic transmission. This mechanism may have important implications for information processing at the cerebellar mossy fiber-granule cell relay, as well as at other central synapses.

\section{REFERENCES}

Bear MF, Malenka RC. Synaptic plasticity: LTP and LTD. Curr Opin Neurobiol 1994; 4: 389-399.

Bliss TVP, Collingridge GL. A synaptic model of memory: long-term potentiation in the hippocampus. Nature 1993; 361: 31-39.

Bortolotto ZA, Bashir, ZI, Davies CH, Collingridge GL. A molecular switch activated by metabotropic glutamate receptors regulates induction of long-term potentiation. Nature 1994; 368: 740-743.

Clark KA, Collingridge GL. Synaptic potentiation of dual-component excitatory postsynaptic currents in the rat hippocampus. J. Physiol. (Lond.) 1995; 482: 39-52.

Collingridge GL, Herron CE, Lester RAJ. Synaptic activation of $\mathrm{N}$-methyl-D-aspartate receptors in the Shaffer collateral-commissural pathway of rat hippocampus. J Physiol (London) 1988a; 399: 283300.

Collingridge GL, Herron CE, Lester RAJ Frequencydependent $\mathrm{N}$-methyl-D-aspartate receptor-mediated synaptic transmission in rat hippocampus. J Physiol (London) 1988b; 399: 301-312.

Davies $\mathrm{CH}$, Collingridge GL. Regulation of EPSPs by the synaptic activation of $\mathrm{GABA}_{B}$ autoreceptors in the hippocampus. J Physiol (London) 1996; 496: 451-470.

D'Angelo E, Rossi P, Taglietti, V. Different proportions of N-methyl-D-aspartate and non-N-methyl-Daspartate receptor currents at the mossy fibergranule cell synapse of developing rat cerebellum. Neuroscience 1993; 53: 121-130.

D'Angelo E, Rossi P, Taglietti V. Voltage-dependent kinetics of N-methyl-D-aspartate synaptic currents in rat cerebellar granule cells. Europ. J Neurosci 1994; 6: 640-645.

D'Angelo E, De Filippi G, Rossi P, Taglietti V. Synaptic excitation of individual rat cerebellar granule cells in situ: evidence for the role of NMDA receptors. J Physiol (London) 1995; 484: 397-413.

D'Angelo E, De Filippi G, Rossi P, Taglietti V. Synaptic activation of $\mathrm{Ca}^{2+}$ action potentials in immature rat cerebellar granule cells in situ. J Neurophysiol 1997a; 78: 1631-1642.

D'Angelo E, Rossi P, Taglietti V. Long-lasting enhancement of mossy fiber-granule cell transmission induced by high-frequency stimulation. J Physiol (London) 1997b;

Ebralidze AK, Rossi DJ, Tonegawa S, Slater NT. Modifi-cation of NMDA receptor channels and synaptic transmission by targeted disruption of the NR2C gene. J Neurosci. 1996; 16: 000 ????????

Edmonds B, Gibb AJ, Colquhoun D. Mechanisms of activation of glutamate receptors and the time course of excitatory synaptic currents. Ann Rev Physiol 1995; 57: 495-519.

Edwards FA, Konnerth A, Sackmann B, Takahashi TA. A thin slice preparation for patch-clamp recordings from neurons of the mammalian central nervous system. Pfluegers Arch 1989; 414: 600-612.

Heggelund P, Hartveit E. Neurotransmitter receptors mediating excitatory input to cells in the cat lateral geniculate nucleus. I. Lagged cells. J Neurophysiol 1990; 63: 1347-1360.

Hestrin S, Nicoll RA, Perkel DJ, Sah P. Analysis of excitatory synaptic action in pyramidal cells using whole-cell recordings from rat hippocampal slices. J Physiol (London) 1990; 422: 203-225.

Iino M, Ozawa S, Tsuzuki K. Permeation of calcium through excitatory amino-acid receptor channels in cultured rat hippocampal neurons. J Physiol 1990; 424: 151-165.

Kasamatsu T, Imamura $\mathrm{K}$, Mataga N, Hartveit $\mathrm{E}$, Heggelund U, Heggelund P. Roles of N-methyl-Daspartate receptors in ocular dominance plasticity in developing visual cortex: re-evaluation. Neuroscience 1998; 82: 687-700.

Keller BU, Konnerth A, Yaari Y. Patch-clamp analysis of excitatory synaptic currents in granule cells of rat hippocampus. J Physiol 1991; 435: 275-293.

Kinney GA, Slater NT. Potentiation of NMDA receptormediated transmission in turtle cerebellar granule cells by activation of metabotropic glutamate receptors. J Neurophysiol 1993; 69: 585-594.

Kirkwood A, Bear MF. Long-term potentiation in the adult and immature visual cortex. In: Conti F, Hicks $P$, eds, Excitatory amino acids and the cerebral cortex. London: MIT Press, 1996; 253-263.

Kullmann DM, Erdemli G, Asztely F. LTP of AMPA and NMDA receptor-mediated signals: evidence for presynaptic expression and extrasynaptic glutamate spill-over. Neuron 1996; 17: 461-474.

Mayer ML, Westbrook GL, Guthrie PB. Voltagedependent block by $\mathrm{Mg}^{2+}$ of NMDA responses in spinal cord neurones. Nature 1984; 309: 261-263.

Mayer ML, Westbrook GL. Permeation and block of Nmethyl-D-aspartic acid receptor channels by divalent 
cations in mouse cultured central neurones. J Physiol (London) 1987; 394: 501-527.

Mayer ML, Vyklicky L Jr, Clements J. Regulation of NMDA receptor desensitisation in mouse hippocampal neurones by glycerine. Nature 1989; 338: 425-427.

MacDonald JF, Mody I, Salter MW. Regulation of Nmethyl-D-aspartate receptors revealed by intracellular dialysis of murine neurones in culture. J Physiol (London) 1989; 414: 17-34.

MacDonald JF. Phosphorylation targets the functional gating of a glutamate channel. J Physiol (London), 1997; 503: 469.

McBain CJ, Mayer ML. N-methyl-D-aspartic acid receptor structure and function. Physiol Rev 1994; 74: 723-760.

Miller KD, Chapman B, Stryker MP. Visual responses in adult cat visual cortex depend on N-methyl-Daspartate receptors. Proc Natl Acad Sci USA 1989; 86: 5183-5187.

Monyer H, Sprengel R, Shoepfer R, Herb A, Higuchi M, Lomeli $\mathrm{H}$, et al. Heteromeric NMDA receptors: molecular and functional distinction of subtypes. Science 1992; 256: 1217-1221.

O'Connor J, Rowan MJ, Anwyl R. Tetanically induced LTP involves a similar increase in the AMPA and NMDA receptor components of the excitatory postsynaptic current: investigations of the involvement of mGlu receptors. J Neurosci 1995; 15: 2013-2020.

Nowak L, Bregestowski P, Asher P, Herbert A, Prochiantz A. Magnesium gates glutamate-activated channels in mouse central neurones. Nature 1984; 307: 462-465.

Rossi P, D'Angelo E, Taglietti V. Differential longlasting potentiation of the NMDA and non-NMDA synaptic currents induced by metabotropic and NMDA receptor coactivation in cerebellar granule cells. Eur J Neurosci 1996; 8: 1182-1189.

Silver RA, Traynelis SF, Cull-Candy SG. Rapid timecourse miniature and evoked excitatory currents at cerebellar synapses in situ. Nature 1992; 355: 163166.

Takahashi T, Feldmeyer D, Suzuki N, Onodera K, CullCandy SG, Sakimura K, Mishina M. Functional correlation of NMDA receptor $\varepsilon$ subunit expression with the properties of single-channel and synaptic current in the developing cerebellum. J Neurosci, in press.

Trussel LO, Zhang S, Raman IM. Desensitization of AMPA receptors upon multiquantal transmitter release. Neuron 1993; 10: 1185-1196.

Turner JP, Leresche N, Guyon A, Soltesz I, Crunelli V. Sensory input and burst firing output of rat and cat thalamocortical cells: the role of NMDA and nonNMDA receptors. J Physiol (London) 1994; 480: 281-295. 

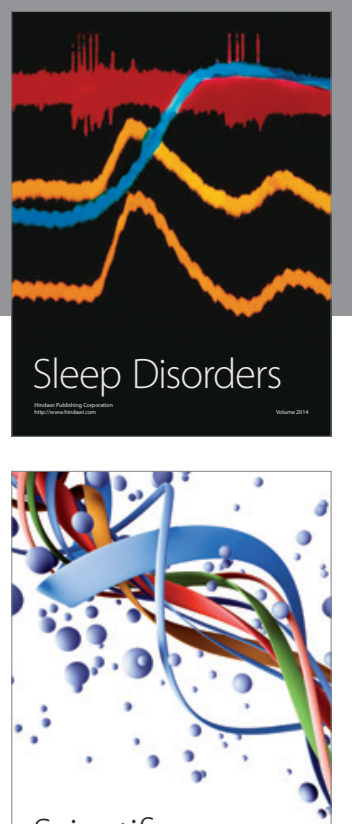

Scientifica
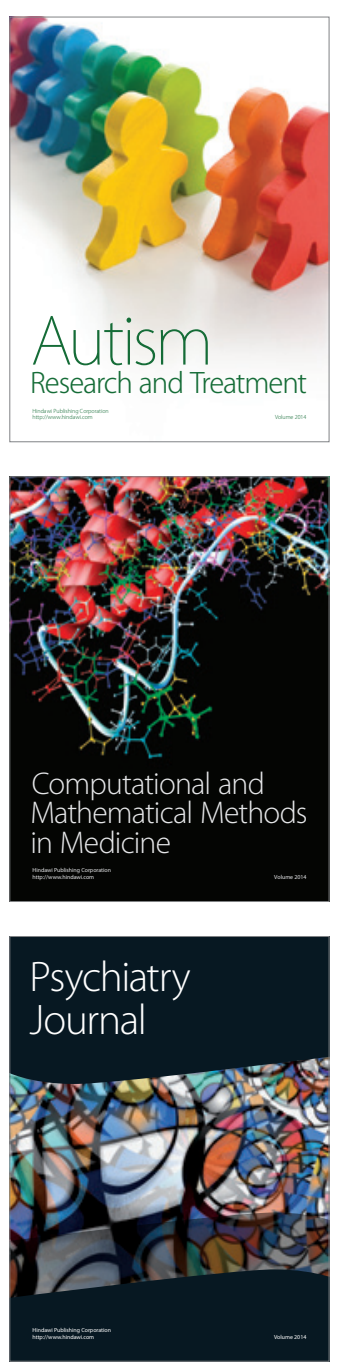
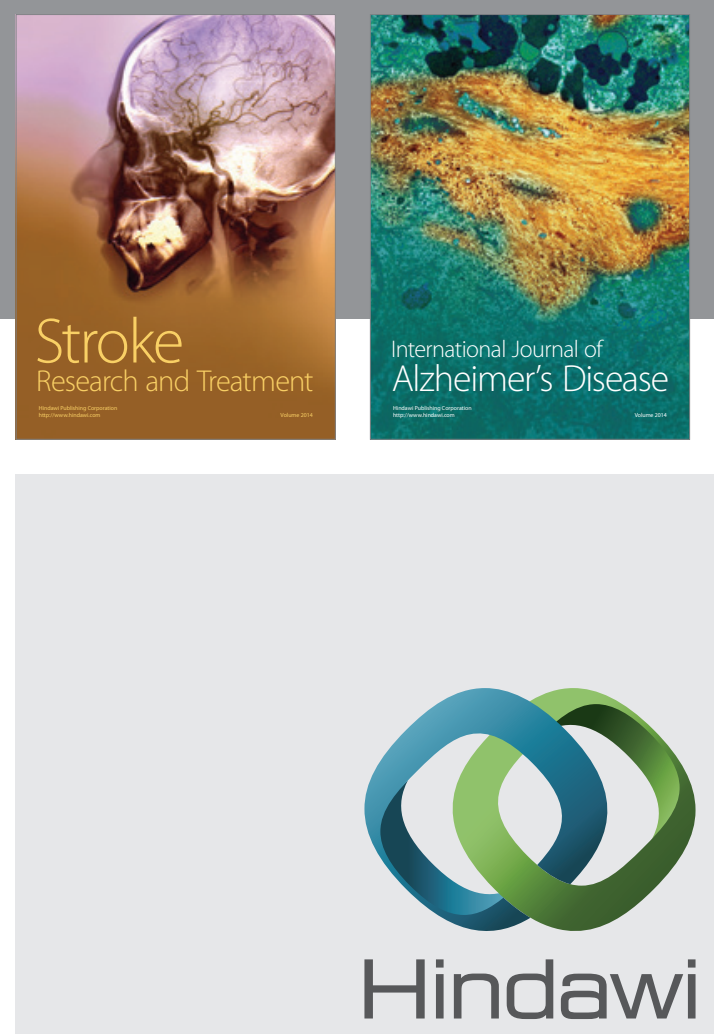

Submit your manuscripts at

http://www.hindawi.com
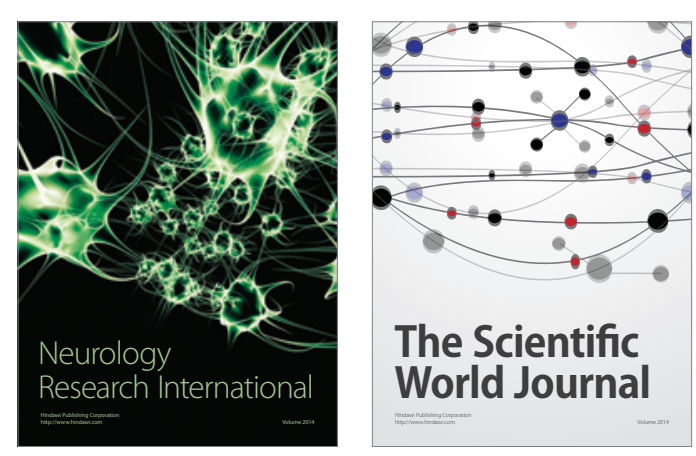

The Scientific World Journal

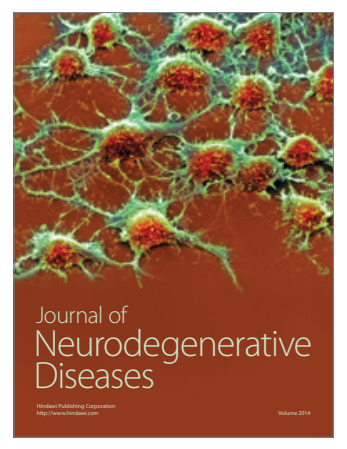

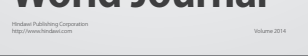

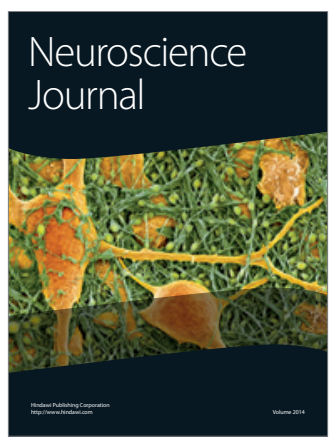

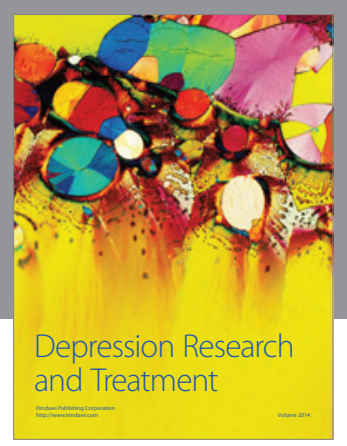
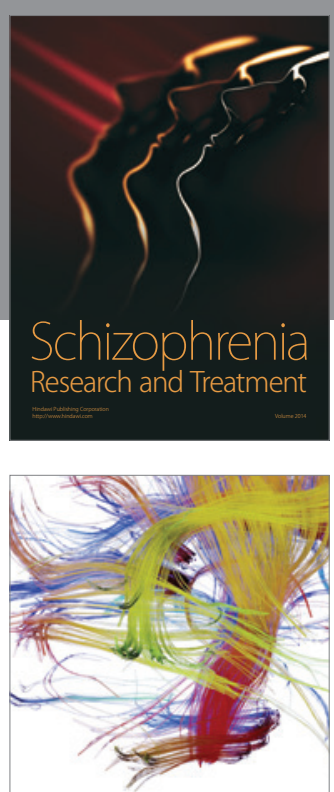

Brain Science

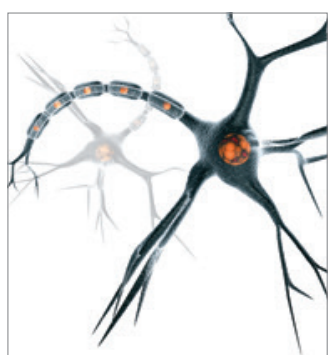

Neural Plasticity
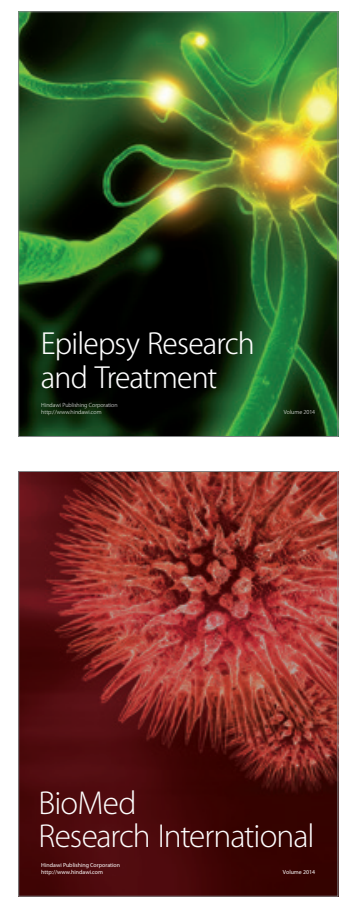

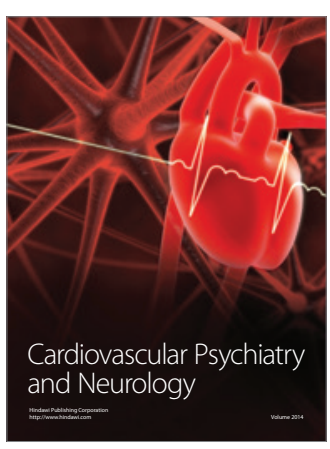

Parkinson's

Disease
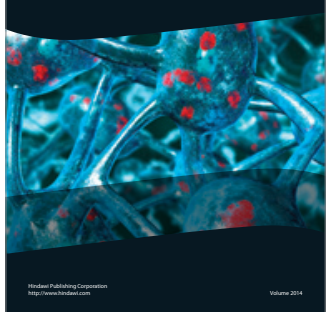